\title{
IN VIVO EVALUATION OF THE SEALING ABILITY OF TWO ENDODONTIC SEALERS IN ROOT CANALS EXPOSED TO THE ORAL ENVIRONMENT FOR 45 AND 90 DAYS
}

\author{
AVALIAÇÃO, IN VIVO, DA CAPACIDADE DE SELAMENTO DE DOIS CIMENTOS \\ ENDODÔNTICOS EM CANAIS RADICULARES EXPOSTOS AO MEIO BUCAL POR 45 E 90 DIAS
}

Patrícia Maria Poli KOPPER ${ }^{1}$, José Roberto VANNI ${ }^{1}$, Álvaro DELLA BONA ${ }^{1}$, José Antônio Poli de FIGUEIREDO ${ }^{1}$, Sérgio PORTO ${ }^{1}$

\author{
1- Specialist and MSc in Endodontics by ULBRA. Professor of Endodontics at the Dental School of Lutheran University of Brazil - Campus \\ Cachoeira do Sul. \\ 2- Specialist and MSc in Endodontics by UFPEL. Senior Professor of Endodontics at the Dental School of University of Passo Fundo. \\ 3- DDS, MMedSci in Restorative Dentistry at the University of Sheffield, UK, and PhD in Biomaterials at the University of Florida, USA. Senior \\ Professor of Prosthodontics at the Dental School of University of Passo Fundo. \\ 4- MSc in Endodontics by UFPEL, PhD in Endodontics by USP. Assistant Professor of Histology and of the Post Graduation Program in \\ Dentistry at UFRGS \\ 5- Senior Professor of Biological Sciences Institute (ICB - UPF).
}

Corresponding address: Patrícia Maria Poli Kopper. Rua dos Pinheiros, 14 - Condomínio Cantegril Fase II. São Lucas. Cep.: $94495-550$. Viamão - Rio Grande do Sul - Brazil. Fone: (51) 446-8895 / (51) 99542157. e-mail: pkopper@terra.com.br.

Received: July 12, 2005 - Modification: September 23, 2005 - Accepted: October 10, 2005

\begin{abstract}
T

Ihis in vivo study evaluated the sealing ability of a resin-based sealer (AH Plus) and a zinc oxide-eugenol sealer (Endofill) in dogs' teeth, exposed to the oral environment for 45 and 90 days. Forty eight lower incisors from 8 dogs were endodonticaly treated. A stratified randomization determined the sealer use in each root canal. All canals were filled using the lateral condensation technique. The excess filling material at the cervical portion of the root canal was sectioned, leaving a 10-mm obturation length inside the canal. Teeth were provisionally sealed with glass ionomer cement for $24 \mathrm{~h}$ and the canals were exposed to the oral environment for either 45 or 90 days. Therefore, the experimental groups were as follows: A45- AH Plus for 45 days; A90- AH Plus for 90 days; E45- Endofill for 45 days; and E90- Endofill for 90 days $(\mathrm{n}=12)$. After the experimental period, the dogs were killed and the lower jaw was removed. The incisors were extracted and the roots were covered with two coats of nail varnish. The teeth were immersed in India ink for $96 \mathrm{~h}$ and submitted to diaphanization. Dye leakage (in $\mathrm{mm}$ ) was measured using stereomicroscopy (10x magnification). The results were statistically analyzed using two-way ANOVA and Tukey test for multiple comparisons (á = 0.05). Group E90 $(2.03 \pm 0.94)$ showed significantly higher mean leakage value than all other groups $(\mathrm{p}<0.001)$. None of the sealers, in both study conditions, were able to prevent dye leakage.

Uniterms: Root canal filling; Leakage; Endodontic sealer.
\end{abstract}

\footnotetext{
RESUMO

E ste estudo in vivo avaliou a capacidade de selamento de um cimento endodôntico resinoso (AH Plus) e um a base de óxido de zinco eugenol (Endofill), em dentes de cães, expostos ao meio bucal, por 45 e 90 dias. Foi realizado o tratamento endodôntico de 48 incisivos inferiores de 8 cães. Uma randomização estratificada determinou o tipo de cimento a ser usado em cada canal que foram tratados pela técnica de condensação lateral. Após a obturação, o excesso de material obturador, na porção cervical do canal radicular foi seccionado, restando o comprimento de $10 \mathrm{~mm}$ no interior do canal radicular. Os dentes foram selados, provisoriamente, com cimento de ionômero de vidro por 24 h. A seguir, o selamento coronário foi removido e os canais ficaram expostos ao meio bucal. Desta forma, delineou-se os seguintes grupos experimentais: A45- AH Plus por 45 dias; A90- AH Plus por 90 dias; E45- Endofill por 45 dias; e E90- Endofill por 90 dias (n=12). Passado o período experimental, os cães foram mortos e as mandíbulas removidas. Realizou-se a exodontia dos incisivos e as suas raízes foram impermeabilizadas com duas camadas de esmalte para unhas. Os dentes foram imersos em tinta nanquim por 96 h. Após realizou-se a diafanização dos espécimes e a infiltração de corante foi medida (em mm) com auxílio de uma lupa esteroscópica, em aumento de 10x. Os resultados foram analisados estatisticamente através da Análise de Variância de dois fatores e Teste de Comparações Múltiplas de Tukey (á = 0.05). O grupo E90 (2.03 \pm 0.94$)$ apresentou uma infiltração média significativamente maior do que a ocorrida nos demais grupos ( $<0.001)$. Os cimentos avaliados, nos dois períodos experimentais, não foram capazes de impedir a infiltração de corante.

Unitermos: Obturação endodôntica; Infiltração; Cimento endodôntico.
} 


\section{INTRODUCTION}

After filling, the absence of infection in the root canal system is a fundamental factor for the prognosis of endodontic treatment. To achieve this goal, the filling material should allow sealing of the root canal at both the tooth apex and the crown.

In the constant search for an ideal material, root canal obturation has been performed with gutta-percha points and endodontic sealers, which act as an agent to bond the points to each other and to the root canal walls. Thus, the endodontic sealer should present properties that render the root canal system impermeable. Grossman ${ }^{9}$ (1958) described eleven requirements that an endodontic sealer should meet, highlighting that it should provide hermetic sealing and be insoluble in the oral fluids.

A frequent concern of dentists is the possibility of exposure of the filling materials to the oral environment. Though undesirable, this clinical situation may occur and can dissolve the endodontic sealer, making the root canal obturation permeable to saliva favoring the communication between irritating agents from the oral cavity and the periradicular tissues, via the apical foramen or lateral canals. Such situation can turn a well done endodontic treatment in a failure ${ }^{20}$.

The required period of exposure to the oral environment to occur such failure has been studied in vitro using different methodologies by Swanson and Madison ${ }^{24}$ (1987), Torabinejad, et al. ${ }^{26}$ (1990), Magura, et al. ${ }^{17}$ (1991), Khayat, et al. ${ }^{11}$ (1993), Gish, et al. ${ }^{8}$ (1994), Trope, et al. ${ }^{27}$ (1995), Barrieshi, et al. ${ }^{3}$ (1997), Alves, et al. ${ }^{1}$ (1998), Siqueira Junior, et al. ${ }^{21}$ (1999), Timpawat, et al. ${ }^{25}$ (2001) and Zucco ${ }^{30}$ (2001).

One aspect that may influence the time required to occur communication of irritating agents between the oral cavity and the periapical tissues is the type of endodontic sealer employed for obturation. Depending on the sealing ability of the sealer, communication may be prevented. This property of different endodontic sealers has been evaluated using several methodologies by Leal, et al. ${ }^{14}$ (1987), Madison, et al. ${ }^{15}$ (1987), Madison and Wilcox ${ }^{16}$ (1988), Kuga, et al. ${ }^{13}$ (1990), Siqueira Junior, et al. ${ }^{19}$ (1995), Haïkel, et al. ${ }^{10}$ (1999), De Almeida, et al. ${ }^{5}$ (2000), Valera, et al. ${ }^{28}$ (2000), Timpawat, et al..$^{25}$ (2001), Zucco ${ }^{30}$ (2001), Çobankara, et al. ${ }^{4}$ (2002), Barbosa, et al. ${ }^{2}$ (2003), Gençoglu, et al. ${ }^{7}$ (2003), Kopper, et al. ${ }^{12}$ (2003).

Yet, there are few studies in the literature evaluating the relationship between the sealing ability of endodontic sealers and the time during which the material is left in contact with the oral fluids. Siqueira Junior, et al. ${ }^{21}$ (1999), Timpawat, et al. $^{25}$ (2001) and Zucco ${ }^{30}$ (2001), employing different endodontic sealers, achieved results that allow this correlation.

Most aforementioned studies were in vitro investigations, in which the experimental conditions impair reproduction of the biocharacteristics of the oral cavity. The masticatory activity, thermal cycling, oral microbiota, variations in the salivary flow and food impaction, which may occur if the root canal is left unsealed, constitute situations in the oral environment that are hardly reproduced in the laboratory.

In an attempt to complement the existing literature and minimize the limitations of in vitro investigations, the present study comprised an in vivo evaluation of the sealing ability of a resin-based sealer (AH Plus) and a zinc oxide-eugenol sealer (Endofill) in dogs' teeth exposed to the oral environment for either 45 or 90 days, testing the hypothesis that the resin-based sealer result in lower leakage than the zinc oxide-eugenol sealer after 90 days.

\section{MATERIALAND METHOD}

The present study was approved by the Research Ethics Committee of the Dental School of the University of Passo Fundo (CEP n. 290/2004).

It was used 48 lower incisors of 8 small mongrel dogs of unknown age. Dogs have three lower incisors at each hemiarch (central, intermediate and lateral incisor), with only one canal each. Thus, the total study sample was 48 root canals.

Initially, treatment was performed in the lower right incisors, which were left exposed to the oral environment for 90 days. Forty-five days later, the same dogs had their lower left incisors treated and these root canals were left exposed for 45 days. Therefore, the sample contained 24 teeth in each study period.

In each of the two afore mentioned experimental procedures, the dogs were submitted to general anesthesia, receiving, initially, an intra-muscular injection of $15 \mathrm{ml} / \mathrm{kg}$ of ketamine (Francotar ${ }^{\circledR}$ - Virbac do Brasil Indústria e Comércio Ltda., Roseira, Brazil), 1ml/kg of xylazine hydrochloride (Virbaxyl ${ }^{\circledR}$ 2\% - Virbac do Brasil Indústria e Comércio Ltda., São Paulo, Brazil) and $0.044 \mathrm{ml} / \mathrm{kg}$ of atropine sulfate (Atropina 1\% FRAGA - Farmagrícola S.A. Importação e Exportação, Mairiporã, Brazil). Following, the dogs received $0.9 \%$ sodium chloride $(\mathrm{NaCl})$ intravenously (Laboratório JP. - Indústria Farmacêutica S.A., Ribeirão Preto, Brazil). The animals were intubated and received $100 \%$ oxygen. The $0.9 \%$ $\mathrm{NaCl}$ and $100 \%$ oxygen were kept throughout the procedure. Anesthesia was maintained by intravenous application of $5 \mathrm{ml} / \mathrm{kg}$ of ketamine and $0.33 \mathrm{ml} / \mathrm{kg}$ of xylazine hydrochloride, at 30-min intervals ${ }^{12}$.

Before onset of the clinical procedures, antisepsis of the soft tissue and teeth was performed with a gauze soaked in iodine alcohol (Farmácia escola ULBRA, Canoas, Brazil), and the lower incisors were radiographed.

To access the root canal, a coronal opening was performed on the buccal side of teeth using a round diamond bur n. 1012 (Metalúrgica Fava Indústria e Comércio Ltda., Francisco da Rocha, Brazil) at high-speed and under water cooling. Odontometry was conducted by the radiographic technique, establishing the real working length (RWL) at 1 $\mathrm{mm}$ short of the radiographic apex. The reference point in all cases was the incisal edge of the tooth being treated.

The serial technique was employed for the chemicalmechanical preparation. Root canal instrumentation was performed with $1^{\text {st }}$ series Flexofile ${ }^{\circledR}$ files (Maillefer 
Instruments SA, Ballaigues, Switzerland). Instrumentation initiated with the file that tightly penetrated to the RWL, finishing up using file n. 40. Root canal irrigation was performed alternating between $1 \%$ sodium hypochlorite (Farmácia Escola - ULBRA, Canoas, Brazil) and 17\% trisodium EDTA(Farmácia Escola - ULBRA, Canoas, Brazil) at pH 7.3, using $1.8 \mathrm{ml}$ of solution per change of instrument. The irrigation procedure always initiated and finished using $1 \%$ sodium hypochlorite solution ${ }^{22}$. Finishing the chemicalmechanical preparation, the root canals were dried using absorbent paper points n. 40 (Dentsply Indústria e Comércio Ltda., Petrópolis, Brazil).

Root canal obturation was performed by the lateral condensation technique, using primary gutta-percha points (Dentsply Indústria e Comércio Ltda., Petrópolis, Brazil) and B7 accessory gutta-percha points (TANARI ${ }^{\circledR}$ - Tanariman Industrial Ltda., Manacapuru, Brazil) and one of the following endodontic sealers: Endofill (Dentsply, Indústria e Comércio Ltda., Petrópolis, Brazil) or AH Plus (Dentsply DeTrey GmbH, Konstanz, Germany). The sealers were prepared following the manufacturers' instructions.

A stratified randomization determined, previously, the endodontic sealer to be used in each canal. Eight charts, one for each unknown dog, were set before the experimental procedures. Once the chemical-mechanical preparation of the root canals of one dog was completed, a chart was randomly assigned to that dog. This random assignment was followed until there was only one chart, which was assigned to the last dog submitted to treatment. The experimental period, teeth and endodontic sealer employed in each canal were recorded in the charts. The randomization method contemplated a uniform distribution of the sealers between the groups of teeth (central, intermediate and lateral incisors) at each study period. Yet, none of the dogs had all root canals filled with same sealer. Therefore, the 4 study groups used 12 root canals $(\mathrm{n}=12)$, summarized as follows:

A45- Root canal sealed with AH Plus and exposed to the oral environment for 45 days;

A90- Root canal sealed with AH Plus exposed for 90 days;

E45- Root canal sealed with Endofill exposed for 45 days; and

E90- Root canal sealed with Endofill exposed for 90 days.

After completion of lateral condensation, a periapical radiograph was taken to check if the root canal filling was radiographically adequate. The gutta-percha points were sectioned with aid of a plugger (Duflex ${ }^{\circledR}$ - SS White Artigos Dentários Ltda., Rio de Janeiro, Brazil) heated over a flame (Standar Evang Indústria e Comércio Ltda, São Paulo, Brazil), removing the excess material from the interior of the pulp chamber. Mild pressure was then applied in apical direction (vertical condensation) with a Paiva plugger n. 2 (Golgran Indústria e Comércio de Instrumentos Odontológicos Ltda., Pirituba, Brazil). Paiva pluggers n. 1 and n. 2, heated over a flame, were used to section the remaining obturation material at the cervical level leaving a $10-\mathrm{mm}$ long obturation material inside the root canal. To achieve this length of remaining material, the bidigital spacer A (Maillefer Instruments SA,
Ballaigues, Switzerland) was calibrated, with silicone stops, to the dimension of the RWL minus $10 \mathrm{~mm}$. Sectioning of the filling material was done when the stop of the bidigital spacer A touched the reference point.

A cotton pellet was placed into the pulp chamber, over the root canal treatment, and a temporary seal with glass ionomer cement (Vidrion $\mathrm{R}^{\circledR}$ - SS White Artigos Dentários Ltda., Rio de Janeiro, Brazil) was applied over it for $24 \mathrm{~h}$. This material was prepared according to the manufacturer's instructions and was placed using a Centrix Mark III syringe (Centrix Incorporated, USA) to fill the entire coronal cavity.

After $24 \mathrm{~h}$, the dogs were once again anesthetized with a single intramuscular injection of $15 \mathrm{ml} / \mathrm{kg}$ of ketamine and $1 \mathrm{ml} / \mathrm{kg}$ of xylazine hydrochloride, and the coronal sealing was removed with a diamond bur n. 1012 at high-speed, under cooling. Thus, the root canal treatments were exposed to the oral environment.

After the experimental period, the dogs were submitted to surgical procedures conducted by students of the discipline of Experimental Anatomy of the Medical School of UPF, the dogs received an excessive dose of $3 \%$ sodium pentobarbital (Hypnol ${ }^{\circledR}$, Cristalia, Produtos Químicos e Farmacêuticos Ltda., Itatiba, Brazil) and died. Important to mention that eight dogs were previously assigned to the surgical procedures in the Medical School then the authors got permission from the Ethics Committee to assign these dogs to this research project.

With a handle n. 4 (J.O.N. Comércio de Produtos Odontológicos Ltda., São Paulo, Brazil) and blade n. 22 (Becton Dickinson Indústrias Cirúrgicas Ltda., Juiz de Fora, Brazil), the soft tissues in the mandible were dissected until the periosteum was reached. The mandible was sectioned bilaterally using a saw (TDV Dental Ltda., Pomerode, Brazil) between the canine and the first premolar, making three jaw blocks, being one anteriorly, used in this study, and two posteriorly, used in other studies, following the same line of investigation. The dogs remains were placed in a septic deposit at the UPF.

The lower incisors were extracted using, initially, a carbide bur n. 8 (KG Sorensen Ind. e Com. Ltda., Barueri, Brazil), at high-speed under cooling, to remove the buccal bone plate until close the teeth roots. Then, a Le Cron instrument (Duflex ${ }^{\circledR}$ - SS White Artigos Dentários Ltda., Rio de Janeiro, Brazil) was employed to completely remove the buccal bone plate. A spatula n. 7 (Duflex - SS White Artigos Dentários Ltda., Rio de Janeiro, Brazil) was placed at the proximal aspects of the tooth and, with levering movements, the tooth was displaced from its socket. After extraction, the teeth were placed in capped test tubes, properly identified.

The pulp chamber of each tooth was thoroughly irrigated with distilled water (Farmácia Escola - ULBRA, Canoas, Brazil) using a 5-ml disposable plastic syringe (Becton Dickinson Indústrias Cirúrgicas Ltda., Juiz de Fora, Brazil) and a hypodermic needle 25/4 (Ibras Indústrias Cirúrgicas S.A, Campinas, Brazil). Simultaneously to the irrigation procedure, aspiration was performed with a suction canula n. 20 (Becton Dickinson Indústrias Cirúrgicas Ltda, Juiz de 
Fora, Brazil). When the distilled water flowed back clear from the pulp chamber the irrigation was interrupted and suction was kept for nearly $10 \mathrm{~s}$.

The roots were coated with two layers of clear nail varnish (Risqué - Niasi S/A, São Paulo, Brazil), including the apical foramen, and allowed to dry. The specimens were immersed in India ink (Trident S.A. Indústria de Precisão, Itapuí, Brazil) at neutral $\mathrm{pH}$ for $96 \mathrm{~h}$ and washed under tap water for $1 \mathrm{~h}$. The specimens were rendered transparent using the diaphanization technique described by Garberoglio and $\operatorname{Bassa}^{6}$ (1983).

The transparent teeth were analyzed under stereomicroscopy (GSZ, Zeiss, Germany) with 10x magnification and a measuring ocular. The India ink leakage was measured (in mm), considering each root as a whole. Ink penetration values were recorded for several locations in each root. However, only the largest value, divided by the magnification (10), was considered for each specimen. An experienced examiner performed all measurements, in a blind study.

Results were statistically analyzed using two-way analysis of variance (Anova) and mean differences were analyzed by Tukey test for multiple comparisons (SAS software version 8.0$)$ at $5 \%$ significance level $(a=0.05)$.

\section{RESULTS}

Two teeth, one from Group A45 and another from Group E90, fractured during the extraction procedure. Thus, these two groups end up having 11 specimens.

Mean and standard deviation values $(\mathrm{mm})$ of dye penetration for the experimental groups, and the statistical groupings are presented in Table 1 . The descriptive statistics is summarized in Table 2.

Two-way Anova revealed significant interaction between time and sealer, meaning that there is a combined effect of these two factors in leakage. Tukey test for multiple comparisons showed that the mean leakage value of Group E90 is significantly higher than the mean values of all other groups.

\section{DISCUSSION}

Preventing contamination or recontamination of the root canal system after completion of endodontic therapy is still a challenge for the dental professional. In the absence of impermeable sealing of the root canal system, failure of endodontic therapy may ensue. Evidences indicate that the endodontic failure is closely related to the constant presence of microorganisms in the root canal and periapical tissues after obturation ${ }^{18,23}$. Such contamination may occur because of the ability of these microscopic organisms to permeate the obturation mass, inducing or maintaining a periapical lesion.

The microbial leakage occurs both in apical-cervical and cervical-apical directions; the following situation may occur when there is absence of coronal sealing with consequent exposure of the root canal to the oral fluids, allowing

TABLE 1- Mean and standard deviation (SD) values (in $\mathrm{mm}$ ) of dye penetration for the experimental groups. The statistical groupings are following the mean values

\begin{tabular}{|c|c|c|c|c|c|c|}
\hline \multirow{3}{*}{$\begin{array}{l}\text { Exposure time } \\
\text { (in days) }\end{array}$} & \multicolumn{4}{|c|}{ Sealer } & \multicolumn{2}{|c|}{ Total } \\
\hline & \multicolumn{2}{|c|}{ AH Plus } & \multicolumn{2}{|c|}{ Endofill } & \multirow[b]{2}{*}{ Mean } & \multirow[b]{2}{*}{ SD } \\
\hline & Mean & SD & Mean & SD & & \\
\hline 45 & $0.39^{\mathrm{B}}$ & 0.41 & $0.55^{\mathrm{B}}$ & 0.39 & 0.47 & 0.40 \\
\hline 90 & $0.39^{\text {в }}$ & 0.35 & $2.03^{A}$ & 0.94 & 1.17 & 1.08 \\
\hline Total & 0.39 & 0.37 & 1.26 & 1.03 & 0.82 & 0.88 \\
\hline
\end{tabular}

Mean values followed by different letters are significantly different at the significant level of $5 \%$.

TABLE 2- Descriptive statistics for the two-way analysis of variance (Anova)

\begin{tabular}{lcccc}
\hline Source of variation & Degrees of freedom & Sum of squares & F & p \\
\hline Time & 1 & 6.27 & 19.35 & $<0.001$ \\
Sealer & 1 & 9.24 & 28.52 & $<0.001$ \\
Time*Sealer & 1 & 6.26 & 19.31 & $<0.001$ \\
Experimental error & 42 & 13.61 & & \\
Corrected total & 45 & 34.74 & & \\
\hline
\end{tabular}


communication of the components of the oral microbiota with the obturation material.

The time of exposure to the oral environment, associated to the type of endodontic sealer employed for root canal obturation, are important factors that may interfere with the success of endodontic therapy when the afore mentioned clinical condition occurs. The present study attempted to correlate these two factors (time and type of sealer) at two study periods (45 and 90 days) and two endodontic sealers: a Grossman sealer (Endofill), which acted as control, since it is the most widely investigated sealer in the history of Endodontics, and a resin-based sealer (AH Plus), which has demonstrated good outcomes as to its sealing ability ${ }^{5,10,12,30}$.

As in the present investigation, previous in vitro studies also associated the afore mentioned factors ${ }^{21,25,30}$. Despite allowing the control of important variables that may interfere with the outcomes, such studies conducted in laboratory present some limitations, as the fact that they do not allow association of all situations occurring in the oral cavity, such as: chewing activity, thermal cycling, oral microbiota, variations in salivary flow, and food impaction. The present study aimed to minimize the limitations of such studies, simulating the conditions of the oral environment, using dogs as an experimental model. A similar model was used by Barbosa, et al. ${ }^{2}$ (2003) and Kopper, et al. ${ }^{12}$ (2003). Barbosa, et al. ${ }^{2}(2003)$ used histological sections from dog's teeth and evaluated the healing process. This method provides good understanding of the impact of contamination on the tissue surrounding the periapical area of the tooth. However, it does not give a three-dimensional view of the sealing ability, as given by Kopper, et al. ${ }^{12}$ (2003).

It should be highlighted that, before onset of the clinical procedures, the dogs received atropine sulfate and were intubated. These conditions allowed accomplishment of endodontic therapy without utilization of rubber dam, since the tube prevented interference from breathing and the atropine inhibited the salivary flow.

As in the studies of Swanson and Madison ${ }^{24}$ (1987), Madison, et al. ${ }^{15}$ (1987), Madison and Wilcox ${ }^{16}$ (1988), Magura, et al. ${ }^{17}$ (1991) and Kopper, et al. ${ }^{12}$ (2003), the teeth were rendered transparent via diaphanization to allow for the observation of dye leakage, providing a threedimensional image of the root canals. This procedure allowed for the quantification of the highest degree of leakage in each root canal.

The results of this study confirm the inability of the root canal filling to keep an impermeable sealing after the exposure to the oral environment as soon as 45 days. The two endodontic sealers used in this study were unable to prevent dye leakage, indicating that there was room in the obturation mass for possible microbial leakage to some extent.

As shown in Table 1, there is no significant differences in mean leakage values between the sealers at 45 days (Groups A45 and E45). This finding disagree with those of Kopper, et al. ${ }^{12}$ (2003), who employed a similar experimental model as the present study and observed that $\mathrm{AH}$ Plus presented a lower mean leakage value compared to the mean value of Endofill at 45 days. However, in the Kopper, et al. ${ }^{12}$ (2003) study, the root canals were additional prepared for post, which is not the case of the present study.

Specimens in Group E90 showed the highest mean leakage value. This finding suggests that the oral environment exposure time and the type of endodontic sealer are important factors that, in combination, may interfere with the success of endodontic therapy.

Analysis of the data reveals that the chances of failure in root canals obturated with gutta-percha and Endofill, exposed to the oral environment for 90 days (Group E90) are higher than in root canals obturated with gutta-percha and AH Plus, submitted to the same clinical conditions (Group A90). This observation is in accordance with the findings of Zucco ${ }^{30}$ (2001), who observed, in vitro, a higher sealing ability for the AH Plus compared to the Endofill, at an experimental period of 90 days.

Based on the present and previous studies, the endodontic filling materials investigated cannot provide an impermeable obturation, as recommended by Grossman ${ }^{9}$ (1958), who described the characteristics of an ideal endodontic sealer. Yet, several experimental models have been employed to evaluate the sealing ability of these materials, yielding different resuts ${ }^{29}$.

The experimental model employed provided an adequate insight on the effect of oral conditions on endodontically treated teeth left without coronal sealing for 45 and 90 days. Future studies on the periapical tissue response along with the information achieved in this study may contribute for an understanding of the phenomena interfering with the success of endodontic therapy.

\section{CONCLUSIONS}

Based on the research protocol and results of the present study, it can be stated that:

- After 45 days of exposure to the oral environment, the endodontic sealers tested were not able to keep the root canal impermeable and prevent coronal dye leakage.

- The endodontic sealer, Endofill, after 90 days of exposure to the oral environment, presented lower sealing ability compared to the 45-day period and with AH Plus at both periods.

\section{REFERENCES}

1- Alves J, Walton R, Drake D. Coronal leakage: endotoxin penetration from mixed bacterial communities through obturated, post-prepared root canals. J Endod. 1998;24:587-91.

2- Barbosa HG, Holland R, de Souza V, Dezan EJ, Bernabe PF, Otoboni JA, Nery MJ. Healing process of dog teeth after post space preparation and exposition of the filling material to the oral enviroment. Braz Dent J. 2003;14:103-8.

3- Barrieshi KM, Walton RE, Johnson WT, Drake DR. Coronal leakage of mixed anaerobic bacteria after obturation and post space preparation. Oral Surg Oral Med Oral Pathol Oral Radiol Endod. 1997;84:310-4. 
4- Cobankara FK, Adanir N, Belli S, Pashley DH. A quantitative evaluation of apical leakage of four root-canal sealers. Int Endod J. 2002;35:979-84.

5- De Almeida WA, Leonardo MR, Tanomaru Filho M, Silva LAB. Evaluation of apical sealing of three endodontic sealers. Int Endod J. 2000;33:25-7.

6- Garberoglio R, Bassa S. O dente transparente. ARS CVRANDI Odontologia 1983;9:5-7.

7- Gençoglu N, Türkmen C, Ahiskali R. A new silicon-based root canal sealer (Roekoseal ${ }^{\circledR}$ - Automix). J Oral Rehabil. 2003;30:753-7.

8- Gish SP, Drake DR, Walton RE, Wilcox L. Coronal leakage: bacterial penetration through obturated canals following post preparation. J Am Dent Assoc. 1994;125:1369-72.

9- Grossman LI. An improved root canal cement. J Amer Dent Assoc. $1958 ; 56: 381-5$

10- Haïkel Y, Wittenmeyer W, Bateman G, Bentaleb A, Allemann C. A new method for the quantitative analysis of endodontic microleakage. J Endod. 1999;25:172-7.

11- Khayat A, Lee SJ, Torabinejad M. Human saliva penetration of coronally unsealed obturated root canals. J Endod. 1993;19:458-61.

12- Kopper PMP, Figueiredo JAP, Della Bona A, Vanni JR, Bier CA, Bopp S. Comparative in vivo analysis of the sealing ability of three endodontic sealers in post-prepared root canals. Int Endod J. 2003;36:857-63.

13- Kuga MC, Kavahara EM, Del’Hoyo RB, Berbert A. Infiltração marginal em obturações de canais radiculares decorrentes de materiais obturadores. Rev Paul Odontol.1990;12:2-6.

14- Leal JM, Bonetti $F^{\circ}$ I, Leonardo MR, Simöes $F^{\circ}$ AP, Esberard RM, Dias M, Ary J. Sealapex, AH 26 Silver Free e Fill Canal: avaliação in vitro do selamento apical através da infiltração do corante rodamina B a 2\%. Influência do tempo de armazenagem. Rev Bras Odont. 1987;44:8-14.

15- Madison S, Swanson K, Chiles SA. An evaluation of coronal microleakage in endodontically treated teeth. Part II: sealer types. J Endod. 1987;13:109-12.

16- Madison S, Wilcox LW. An evaluation of coronal microleakage in endodontically treated teeth. Part III: in vivo study. J Endod. 1988;14:455-8.

17- Magura ME, Kafrawy AH, Brown CE, Newton CW. Human saliva coronal microleakage in obturated root canals: an in vitro study. J Endod. 1991;17:324-31.

18- Nair PNR, Sjögren U, Krey G, Kahnberg KE, Sundqvist G. Intraradicular bacteria and fungi in root-filled, asymtomatic human teeth with therapy-resistant periapical lesions: a long-term light and electron microscopic follow-up study. J Endod. 1990;16:580-8.

19- Siqueira Junior JF, Fraga RC, Garcia PF. Evaluation of sealing ability, $\mathrm{pH}$ and flow rate of three calcium hydroxide-based sealers. Endod Dent Traumatol. 1995;11:225-8.

20- Siqueira Junior JF, Lopes HP, Elias CN. Obturação do sistema de canais radiculares. In: Lopes HP, Siqueira Junior JF. Endodontia biologia e técnica. Rio de Janeiro: Medsi; 1999. p. 451-84.

21- Siqueira Junior JF, Rôças IN, Lopes HP, Uzeda M. Coronal leakage of two root canal sealers containing calcium hydroxide after exposure to human saliva. J Endod. 1999;25:14-6.
22- Só MVR. Avaliação da capacidade de limpeza das soluções de hipoclorito de sódio a $1,5 \%$ e EDTA a $17 \%$ utilizadas isolada ou alternadamente durante o preparo do canal radicular. Canoas; 1999. (Dissertação de Mestrado em Odontologia - Faculdade de Odontologia da Universidade Luterana do Brasil).

23- Sundqvist G, Figdor D, Persson S, Sjögren U. Microbiologic analysis of teeth with failed endodontic treatment and the outcome of conservative re-treatment. Oral Surg Oral Med Oral Pathol. 1988;85:86-93.

24- Swanson K, Madison S. An evaluation of coronal microleakage in endodontically treated teeth. Part I: time periods. J Endod. 1987;13:56-9.

25- Timpawat S, Amornchat C, Trisuwan W. Bacterial coronal leakage after obturation with three root canal sealers. J Endod. 2001;27:36-

26- Torabinejad M, Ung B, Kettering JD. In vitro bacterial penetration of coronally unsealed endodontically treated teeth. J Endod. 1990;16:566-9.

27- Trope M, Chow E, Nissan R. In vitro endotoxin penetration of coronally unsealed endodontically treated teeth. Endod Dent Traumatol. 1995;11:90-4.

28- Valera MC, Barbieri M, Menezes MM, Guimarães MP. Efeito da saliva sobre canais obturados, preparados para núcleo e impermeabilizados com cianoacrilatos. J Bras Endo/Pério. 2000;1:6771.

29- Wu MK, WESSELINK PR. Endodontic leakage studies reconsidered. Part I: methodology, application and relevance. Int Endod J. 1993;26:37-43.

30- Zucco LR. Avaliação da infiltração coronária em canais obturados e preparados para pino. Canoas; 2001. (Dissertação de Mestrado em Odontologia - Faculdade de Odontologia da Universidade Luterana do Brasil). 